\title{
Fysik och kemi i fokus för kommunikationen mellan lärare och barn i förskolan
}

\author{
Marie Fridberg \\ Agneta Jonsson \\ Andreas Redfors \\ Susanne Thulin
}

\author{
Högskolan Kristianstad
}

\begin{abstract}
Den här artikeln sammanfattar resultaten från tre studier om förskollärares och barns samtal under naturvetenskapliga aktiviteter, där kreativt skapande varit en del av upplägget. Resultatet visar hur möjligheten till lärande kan hindras när förskollärare och barn har fokus på olika delar i en undervisningssituation och ger exempel på vad man som lärare kan tänka på för att gemensamt fokus ska bibehållas. Studierna pekar även ut möjliga fallgropar att som förskollärare vara medveten om i arbetet med ett naturvetenskapligt lärande, till exempel abstraktioner. Slutligen diskuteras de kommunikationsmönster som kunnat identifieras hos förskollärare och barn i de naturvetenskapliga aktiviteterna.
\end{abstract}

\section{Inledning}

Skolinspektionen [1] har visat på stora skillnader i hur förskolepersonal tar sig an sitt pedagogiska uppdrag och att undervisning om läroplansområdet naturvetenskap antingen undviks eller bedrivs som avgränsade aktiviteter i många förskolor. Att förskolepersonal erbjuds kompetensutveckling inom ämnet är därför viktigt. I den här artikeln beskriver vi forskningsstudier från ett treårigt kompetensutvecklingsprojekt på temat fysik och kemi som vi genomfört tillsammans med samtliga förskollärare, barnskötare och rektorer, ca 150 personer, i ett skolområde i södra Sverige (www.hkr.se/fykeforsk). Vår förhoppning är att forskningsresultaten som beskrivs kan inspirera förskollärare att reflektera kring den egna naturvetenskapsundervisningen.

Kompetensutvecklingsprojektet tog avstamp i bilden av naturvetenskap som ett område som ständigt utvecklas genom ett samspel mellan teorier och experiment till en alltmer förfinad berättelse om vår omvärld [2]. De naturvetenskapliga teorierna skiljer sig från hur vi resonerar om motsvarande fenomen i vardagen. Arbetslag i förskolan behöver alltså hitta sätt att kommunicera den förklaringsmodell som används i arbetet med ett visst naturvetenskapligt fenomen. Detta innebär en balansgång, eftersom den underliggande förklaringsmodellen inte får bli för abstrakt för barnen samtidigt som den behöver harmoniera med mer avancerade förklaringar för att gynna barnens fortsatta lärande (ibid).

Samtliga arbetslag i skolområdet deltog i gemensamma föreläsningar och workshops, ledda av oss forskare, om "enkla kemiska processer och fysikaliska fenomen" kopplade till det omgivande samhället [3,4]. Under träffarna deltog arbetslagen i diskussioner om undervisningsstrategier i relation till naturvetenskap, dels i storgrupp tillsammans med oss forskare, dels i smågrupper där bara arbetslagen närvarade. För att omsätta diskussionerna i praktiken valde varje arbetslag ett naturvetenskapligt fenomen att fokusera på i arbetet med barnen. Dessa fenomen valdes så att undervisningen om dem kunde kopplas till omgivande samhälle och barnens vardag. Fenomen som valdes var till exempel vindkraft, vattenrening och vattenförbrukning. Mellan föreläsningarna som hölls på högskolan stämde vi forskare av med representanter för arbetslagen om hur arbetet fortskred och vad som upplevdes som utmanande. Svaren låg sedan till grund för nästa föreläsning med tillhörande diskussioner. Vi hade också en epost-adress dit arbetslagen kunde skriva och ställa frågor till oss när de undrade något om till exempel en viss naturvetenskaplig förklaringsmodell. 
Insamlingen av data började med att vi forskare filmade fem utvalda arbetslag och barnen under deras arbete med de utvalda naturvetenskapliga fenomenen. I nästa datainsamlingsomgång följdes också fem arbetslag, tre av de föregående plus två nya. Resultaten från de två datainsamlingarna redovisas nedan under det vi kallar studie 1-3. Vid insamlingen av datamaterial följdes Vetenskapsrådets riktlinjer för forskningsetik [5], vilket bland annat innebar att medgivande samlades in från deltagande arbetslag, föräldrar och från barnen när vi var ute och dokumenterade deras aktiviteter. Vi forskare hälsade på en stund i respektive förskola för att göra oss bekanta med barnen och frågade i samband med videoupptagningen om vi fick sitta med och filma det de gjorde. Vi var hela tiden uppmärksamma på om barnen ville delta i aktiviteten och svara på våra frågor [6]. Här sökte vi, särskilt gällande de yngsta barnen, samförstånd kring barnens reaktioner med de lärare som deltog och kände barnen mer. I gemensamma projektdiskussioner med arbetslagen kring videodata har barnens ansikten och namn anonymiserats för att undvika igenkänning.

\section{Naturvetenskap och datorplattor - i barnens regi}

Ett av inslagen i kompetensutvecklingsprojektet var en workshop på temat filmskapande om naturvetenskap. Den baserades på en pilotstudie vi forskare gjorde för några år sedan, där nio barn och en förskollärare arbetade med vattnets faser. I olika gruppkonstellationer undersökte förskolläraren och barnen vattnets fasövergångar genom experiment och dokumenterade aktiviteterna med en datorplatta [7,8].

Förskolläraren och barnen använde sig av Timelapse-fotografering, vilket innebar att de ställde in datorplattan för att fotografera till exempel smältande is med ett jämnt tidsintervall. Av fotona barnen tog skapades därefter, med en enkel knapptryckning, en timelapse-film som spelade upp det naturvetenskapliga skeendet snabbare än det går i verkligheten. Timelapse-filmer har fördelen att kunna visa upp ett långsamt skeende i ett snabbare tempo vilket ger en tydligare överblick över vad som egentligen händer. Andra exempel på sådana skeenden eller fenomen kan vara en blomma som slår ut eller ett träds förvandling genom årstiderna. Vår pilotstudie visade hur barnens efterföljande diskussioner om timelapse-filmerna understödde deras reflektioner om vattens faser. De återskapade därefter händelsen i timelapse-filmen i en så kallad slowmation-film på datorplattan. Slowmation är en förkortning av "slow animation" och innebär en stopmotion-film, eller det man ibland kallar dockfilm. Olika material arrangeras och omarrangeras medan filmskaparen fotograferar en serie av bilder som utgör en sekvens. När bildsekvensen spelas upp ser till exempel lerfigurer ut att få liv där de "rör sig" på filmen.

I pilotstudien använde barnen lera och LEGO för att återskapa sin förklaringsmodell till varför vattnet försvann ur en skål (avdunstade). Deras hypotes att vattnet försvann in i skålen diskuterades och skildrades. Förskolläraren fick genom filmskapandet syn på barnens tankar och kunde därigenom utmana dem vidare mot en förståelse av avdunstning. Sammanfattningsvis visade studiens resultat hur timelapse- och slowmationskapande fick barnen att reflektera över förklaringsmodeller under tiden som de kreativt och relativt självständigt utformade sina filmer. En mer utvecklad variant av ovanstående upplägg användes sedan i det kompetensutvecklingsprojekt som vi presenterar här. Denna utvecklade undervisningsmodell består av följande undervisningssituationer:

- Inledande diskussion med barnen om det naturvetenskapliga fenomenet

- Experiment/Övningar med barnen som dokumenteras med datorplatta eller annat kreativt material, beroende på fenomenet (t ex timelapse/slowmotion/foton)

- Gruppdiskussioner med barnen om dokumentationen

- Återskapande av fenomenet i form av t ex stop-motion- eller green screen-film, utifrån barnens förklaringsmodell

- Barnen visar och återberättar sin förståelse, illustrerad i steg 4, för en förskollärare som inte varit med under återskapandet

Samtliga arbetslag i kompetensutvecklingsprojektet provade på undervisningsmodellen i en 
workshop på högskolan genom att skapa stop-motion-filmer där handlingen utgjordes av en förklaringsmodell till ett naturvetenskapligt fenomen. Arbetet med undervisningsmodellen i fem olika barngrupper modifierades sedan utifrån barns erfarenheter och förmågor.

\section{Lärandeobjekt och intersubjektivitet}

Variationsteorin $[9,10]$ användes som teoretiskt ramverk i kompetensutvecklingsprojektet. Centralt i denna teori är att allt lärande förutsätter att medvetandet riktas mot någonting specifikt att lära, ett lärandeobjekt. Vad som utgör ett sådant lärandeobjekt är brett; det kan till exempel handla om faktakunskap men även om en förmåga, låt säga att cykla eller, mer naturvetenskapligt, att observera. Lärandeobjektet kan i sin tur beskrivas utifrån vad läraren menar att barnens medvetande ska riktas mot, eller hur läraren genomför sin undervisning så att barnen ska få möjlighet att lära sig. Ytterligare ett sätt att beskriva lärandeobjektet är utifrån barnens eller elevernas perspektiv, det vill säga hur barnen upplevde lärandet. Som en del av arbetsgången pratade arbetslagen ihop sig om vilket lärandeobjekt de ville rikta barnens uppmärksamhet mot och hur detta skulle göras. De tog bland annat i beaktande vilka erfarenheter barnen hade och hur barnen förstod lärandeobjektet vid starten av undervisningen, och diskuterade i detalj hur arbetslaget ville att de skulle förstå det efter genomförd undervisning.

Förmågan att interagera med någon och att gemensamt rikta uppmärksamhet mot ett innehåll kan ses som en viktig förutsättning för lärande [11]. Men det räcker inte att lärare och barn tittar på samma sak, det behöver även finnas en gemensam förståelse för vad situationen handlar om. Som exempel kan tas fotboll och andra regellekar i barns vardag. Om ett barn förstår reglerna för fotbollsspel kan det hoppa in i de flesta matcher som spelas på skolgårdar runt om i världen eftersom barnet och övriga spelare har en gemensam förståelse för vad spelet går ut på. Denna gemensamma förståelse, en slags överenskommelse, är det vi kallar intersubjektivitet [12]. Att intersubjektivitet mellan deltagarna skapas är av stor vikt vid lärande om ett innehåll. Om ett barn till exempel aldrig har upplevt snö blir det svårare för förskolläraren att etablera intersubjektivitet runt, och skapa förståelse för, vad som händer när snö smälter. Intersubjektivitet i undervisningen kan alltså ses som en förutsättning som ständigt behöver skapas och upprätthållas genom kommunikation mellan de som deltar. Rommetveit [12] beskriver hur intersubjektivitet är mer av en pågående process än ett statiskt tillstånd, där deltagarna försöker etablera tillräcklig gemensam förståelse för att temporärt hålla kommunikationen eller aktiviteten vid liv.

\section{Samtidig hänsyn till lärandeobjektet och barnets perspektiv}

I studie 1 var det förskollärarnas och barnens intersubjektivitet i arbetet med ett naturvetenskapligt lärandeobjekt som intresserade oss. Hur såg egentligen den gemensamma förståelsen ut hos förskollärare och barn i den naturvetenskapsundervisning som vi hade följt? Vi utgick ifrån en forskningsfråga formulerad som:

- Hur kan intersubjektiv kommunikation beskrivas i relation till ett naturvetenskapligt lärandeobjekt?

Vi analyserade videomaterialet från fem olika arbetslag som vi följde i studie 1, där de medverkande barnen var mellan tre och fem år [13]. I denna första studie blev det tydligt att intersubjektivitet, precis som Rommetveit [12] beskriver, är en process där en gemensam förståelse kan etableras, tappas och återerövras i samtliga undervisningssituationer. Ibland har förskollärarna och barnen gemensamt fokus riktat mot lärandeobjektet och emellanåt tappas det gemensamma fokuset för att sedan erövras igen. I kommunikationen mellan förskollärare och barn i arbetet med de naturvetenskapliga lärandeobjekteten kunde vi identifiera två varianter av intersubjektivitet, illusorisk intersubjektivitet och tillräcklig intersubjektivitet [12,14].

Ett exempel där förskolläraren och barnen skenbart pratar om samma sak, så kallad illusorisk 
intersubjektivitet, finns i följande situation där förskolläraren och barnen arbetade med vattenrening. Förskollärarens planerade lärandeobjekt var att olika filter har olika förmåga att rena vatten, vilket var något hon ville att barnen skulle få erfara. För att åstadkomma detta, det vill säga för att iscensätta lärandeobjektet, använde förskolläraren sig av tre 1,5 liters plastflaskor som hon klippte på mitten och skruvade av korkarna på. Övre delen av flaskan sattes upp och ner i den nedre delen så att överdelen bildade en tratt med mynning nedåt. I de tre trattarna satte förskolläraren stenar, sand respektive kaffefilter, se figur 1

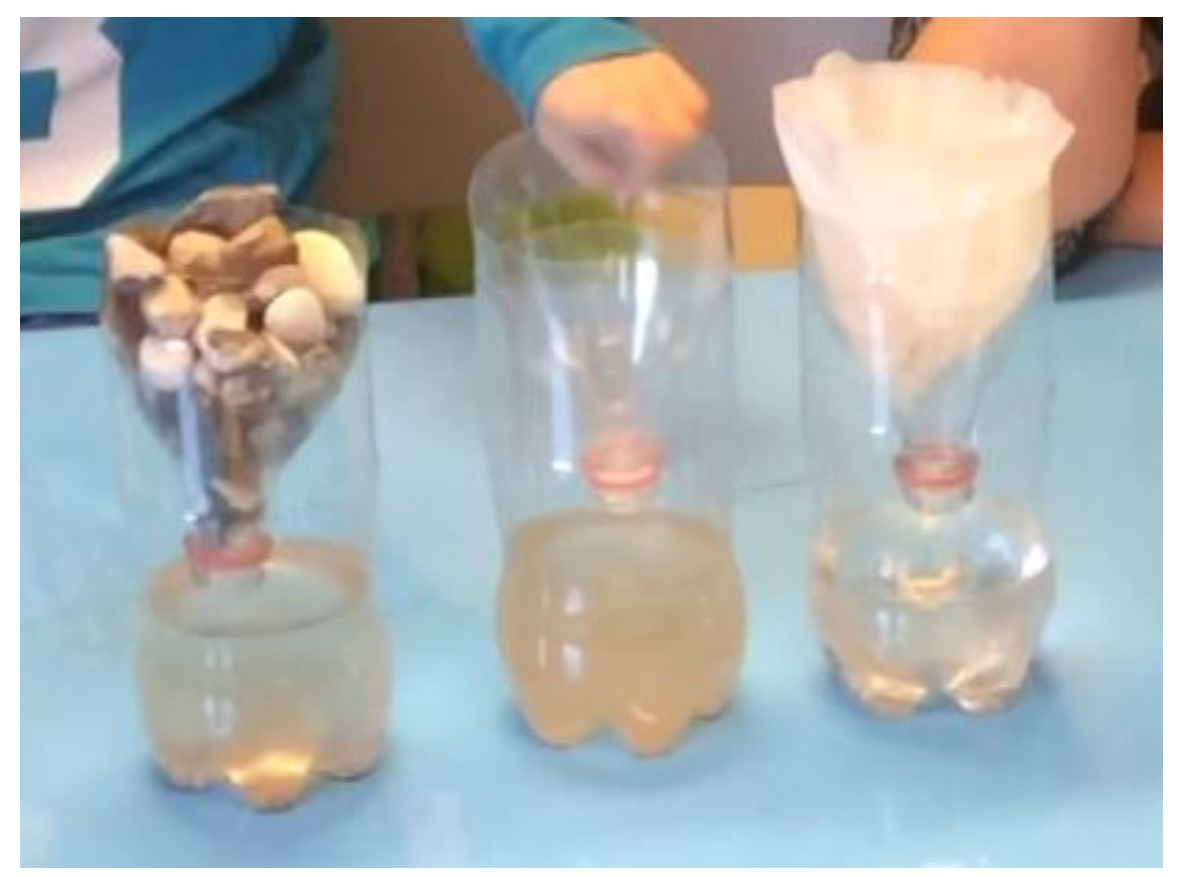

Figur 1. Vattenrening genom plastflaskor med stenar, sand och kaffefilter. På bilden har sanden i mittenflaskan avlägsnats.

Sedan tidigare hade barnen och förskolläraren tittat på smältvatten och för att få större effekt på reningen hade de vid det här tillfället smutsat ner vattnet lite ytterligare med jord från förskolans gård. Förskolläraren och barnen hällde det smutsiga vattnet genom flaskan med stenarna först och lät vattnet rinna igenom till underdelen av flaskan. Det var lika smutsigt när det runnit igenom stenarna som tidigare, och följande diskussion utspelade sig:

\begin{tabular}{|c|c|}
\hline Förskolläraren & $\begin{array}{l}\text { (Håller upp plastflaskan där det smutsiga vattnet nu filtrerats färdigt genom stenarna. Vattnet har } \\
\text { samma bruna färg som tidigare. Flaskans överdel med stenarna sitter kvar i flaskans underdel med } \\
\text { vattnet.) Titta här nu. Blev vattnet rent? }\end{array}$ \\
\hline Barnen & Ja! \\
\hline Förskolläraren & $\begin{array}{c}\text { Är det rent? (Förskolläraren lyfter även upp bringaren med kvarvarande vatten och håller bredvid } \\
\text { plastflaskan med stenarna/filtrerade vattnet) }\end{array}$ \\
\hline Barnen & Ja. \\
\hline Arne & Men det (ohörbart) brunt. \\
\hline Förskolläraren & Blev det brunt? Är vattnet rent om det är brunt? \\
\hline Nero & Ja! \\
\hline Förskolläraren & Är det det? \\
\hline Nero & Ja, titta där! (Visar med handen på stenarna som vattnet filtrerats genom i den övre delen av flaskan.) \\
\hline Förskolläraren & $\begin{array}{l}\text { Ja men titta här. (Sätter ner bringaren men fortsätter hålla upp flaskan med stenarna/filtrerade vattnet } \\
\text { och pekar på vattnet där) }\end{array}$ \\
\hline Förskolläraren & Här har ju vattnet runnit här igenom (visar via stenarna) genom stenarna. (Alla barnen tittar) \\
\hline Nero & Genom stenarna. \\
\hline
\end{tabular}


Förskolläraren höll här upp plastflaskan med stenarna i övre delen och det alltjämt lika smutsiga vattnet i den undre och ställde samtidigt frågan "Titta här nu, blev vattnet rent?". När barnen svarade "ja" verkade det först lite märkligt. Förklaringen kom när Nero pekade på stenarna och sa "Ja, titta där!". Även om förskolläraren och barnen alla hade fokus på flaskan hon höll upp, visade det sig att de hade sitt fokus riktat mot olika delar av systemet, de hade vad vi kallar ett tudelat fokus på lärandeobjektet. Som svar på förskollärarens fråga om vattnet blivit rent fokuserade Nero på stenarna, något vi tolkar som ett uttryck för hans tidigare erfarenhet av ordet "rent". Normalt är det ju inte vattnet som ska bli rent utan man använder vatten för att göra något annat rent, när man till exempel tvättar händerna eller bilen. Kanske kunde intersubjektiviteten ha hjälpts på traven om förskolläraren hade pekat på vattnet, alternativt lyft av tratten med stenarna från flaskan innan hon höll upp vattnet, när hon frågade hur rent vattnet blivit. Ett annat alternativ kunde varit att tala om att man kan använda vatten för att själv bli ren men att det ibland är smuts i vattnet och att vattnet då kan behöva renas. En annan form av illusorisk intersubjektivitet handlar om användande av ett lokalt språk och vardagsord som "den", "det", "det här", "det där". Att använda ord som "den" istället för till exempel "vattenflaskan" öppnar upp för missförstånd och förlorad intersubjektivitet.

Ett exempel på hur tillräcklig intersubjektivitet runt ett lärandeobjekt kan etableras och bibehållas i en situation finns i följande situation, där förskolläraren och barnen arbetade med vindkraft. Förskollärarens uttalade idé om lärandeobjekt var vid nedanstående tillfälle begrepp som till exempel "vindkraft" och "propeller" som barnen skulle få tillgång till genom att erfara ett miniatyrvindkraftverk. Förskolläraren hade byggt ett minivindkraftverk av en flaska och demonstrerade detta för barnen:

\begin{tabular}{|l|r|}
\hline Förskolläraren & Och då tänkte jag visa... (Hon tar fram ett mini-vindkraftverk/flaska) \\
\hline Fatima & Och så detta (visar med handen i luften hur det snurrar). \\
\hline Förskolläraren & Ja, ja. \\
\hline Mario & Det är vindkraften. \\
\hline Förskolläraren & Ja. \\
\hline Mario & Det ser ut som ett flygplan. \\
\hline Förskolläraren & Ja det ser ut som ett flygplan, men detta kallar jag ett vindkraftverk. \\
\hline Mario & Det som du byggde med lego. \\
\hline Förskolläraren & Ja jag byggde, försökte bygga ett igår med lego med. Men hur tror ni detta fungerar, vad behöver vi? \\
\hline Fatima & Blåsa - (Hon visar med handen i luften, runt), lufta. \\
\hline Balli & Vinden. \\
\hline Ari & Detta är som en helikopter. \\
\hline Förskolläraren & Som en helikopter, det kan man också jämföra det med, eller som en propeller. Ska vi kalla den \\
&
\end{tabular}

Det vi ser som ett framgångskoncept i skapandet och bevarandet av tillräcklig intersubjektivitet i ovanstående utdrag var förskollärarens förmåga till en ömsesidig samtidighet [15]. Förskolläraren tog i situationen samtidigt hänsyn till lärandeobjektet hon ville förmedla och till barnens perspektiv och inspel. När Mario kommenterade hur minivindkraftverket såg ut som ett flygplan bekräftade förskolläraren detta, med tillägget att hon kallar det för ett vindkraftverk. När Ari konstaterade utifrån sin erfarenhet att kraftverket påminner om en helikopter bekräftade förskolläraren hans tankar och lade till att man även kan jämföra kraftverkets rotorblad med en propeller. Hon sökte barnens bekräftelse av detta när hon frågade "Ska vi kalla den propeller?". Den här rörelsen fram och tillbaka över vad vi metaforiskt skulle kunna kalla en bro, mellan lärandet man vill uppnå och barnens perspektiv i situationen, kan vara ett verktyg för att som förskollärare skapa och bibehålla 
intersubjektiviteten i undervisningen.

Vidare kan vi konstatera att förskolläraren använde ett så kallat expansivt språk, det vill säga ett mer utvecklat men samtidigt preciserat språk med allmänt vedertagna begrepp. När dessa relateras till barnets sätt att uttrycka sig har vi sett en stark koppling till tillräcklig intersubjektivitet. Att som lärare medvetet använda ett mer exakt språkbruk med för undervisningssituationen korrekta termer samtidigt som barnens perspektiv beaktas möjliggör för barn att skapa kopplingar mellan ett sådant expansivt språk och det egna vardagsspråket. Dessa språkliga kopplingar öppnar i sig upp för ett lärande om fenomenet i fråga, speciellt i sammanhang där konkreta material används [8].

\section{Identifiera delmål på väg mot lärandeobjektet}

I analysen av intersubjektivitet och dess förutsättningar upptäckte vi även något annat intressant. Varje gång intersubjektiviteten bröts kunde vi i situationen identifiera ett mindre lärandeobjekt som behövde förtydligas för barnen. Det behövdes flera små steg på vägen om man så vill, mot det övergripande lärandeobjektet [16]. Upptäckten mynnade ut i studie 2 där vi gjorde en ny analys av datamaterialet från studie 1, men den här gången istället med följande forskningsfråga för ögonen:

- Vilka möjliga förklaringar finns det till att intersubjektiviteten bryts under arbetet med lärandeobjektet?

De små stegen på vägen, eller mellanstegen, kallar vi för intermediära lärandeobjekt och i studie 2 kunde vi kategorisera dem som att tillhöra någon av tre grupperingar: Vardagsord, Teoretiska modeller/begrepp och Abstraktioner. Varje gång intersubjektiviteten bröts kunde åtminstone en del av förklaringen hittas i någon av de tre kategorierna. Ovan nämns vardagsordet "rent" som visade sig betyda något annat för barnen än för förskolläraren. Med teoretiska modeller/begrepp avses förklaringar och begrepp som används inom naturvetenskapen. Som exempel på detta fanns en situation där ordet "skillnad" skapade förvirring. Vi ser ordet skillnad som ett naturvetenskapligt begrepp i sammanhanget; att jämföra olika resultat och utfall är en grundläggande del av naturvetenskapligt arbetssätt. I följande exempel har en förskollärare och ett barn renat vatten genom flaskor, liksom i exemplet ovan, och när de tittade på flaskorna med vattnet utspelade sig följande diskussion:

\begin{tabular}{|l|c|}
\hline Förskolläraren & Vad är det som skiljer? \\
\hline Amar & Denna och denna [tar i en av flaskorna] \\
\hline Förskolläraren & Mm, men hur är den då? \\
\hline Amar & Den är mycket skillnad på och denna är liten. \\
\hline
\end{tabular}

Amar ger uttryck för att vara osäker på ordet skillnad och dess betydelse, alternativt osäker på användningen av det relaterat till förskollärarens fråga om vad som skiljer. Detta belyser behovet av ett intermediärt lärandeobjekt, nämligen ordet "skillnad". På sin väg mot det övergripande lärandeobjektet vattenrening behöver förskolläraren stanna upp och ge barnen möjlighet att förstå betydelsen av ordet skillnad, först då blir fortsatta jämförelser av vattens olika renhet meningsfulla.

Den tredje kategorin intermediära lärandeobjekt rör förskollärarnas användning av abstraktioner. Tanken med abstraktioner/representationer är att förståelsen för fenomenet i fråga ska underlättas men detta förutsätter att barnen har förmåga att abstrahera och omvandla det de tittar på till det som det är tänkt att föreställa. Följande exempel visar hur en abstrakt modell istället kunde komplicera situationen för förskollärare och barn, när de arbetade med att illustrera vattenrening genom ett avloppssystem. Förskolläraren hade en stor glasburk med vatten. Den symboliserade vask, toalettstol och avlopp, och häri hällde hon och barnen olika avfall som barnen kände igen från 
sin vardag:

\begin{tabular}{|l|c|}
\hline Förskolläraren & $\begin{array}{l}\text { Sen så kanske mamma diskar lite [häller i diskmedel] Sen så kanske mamma tvättar lite kläder [häller i } \\
\text { tvättmedel] Om vi använder vasken så kanske vi ... kanske vi äter middag - orkar inte dricka upp juicen }\end{array}$ \\
\hline Oscar & snart kommer det att svämma över ... \\
\hline Förskolläraren & Nu går vi på toa igen ['spolar’, dvs häller vatten I burken] \\
\hline Förskolläraren & Sen har vi lite spa hemma med Mamma och kanske ta bort lite smink ... eller Pappa ... \\
\hline Oscar & Vi måste spola ... \\
\hline Oscar & Nu måste vi nog sluta spola! \\
\hline
\end{tabular}

I ovanstående exempel syns ett brott i intersubjektiviteten runt den valda representationen av avloppssystemet. Det vi uppfattar som svårt för barnen är att allt avfall, vare sig det i verkligheten spolas ner i toaletten eller i köks- eller badrumsvasken, åkte i samma "vask" i form av glasburken. Det var kanske inte självklart för barnen att glasburken kunde sägas representera ett avloppsrör längre ner i systemet, där flera rör finns sammankopplade från vaskar och toalettstolar. Oscar pratade om behovet av att spola, något som tyder på att han tolkade glasburken som en toalett. Till skillnad från ett riktigt avloppsystem blev glasburken full av avfall med risk för översvämning, något Oscar noterade. Det här skapade ett hinder i modellen, ett hinder som inte existerar i verkligheten och Oscar riktade sin uppmärksamhet mot hindret när han konstaterade att "Nu måste vi nog sluta spola!".

\section{Kommunikationsmönster i arbetet med fysik och kemi i förskolan}

I analysen av videomaterialet blev vi även nyfikna på om det skulle gå att urskilja ett mönster i kommunikationen som pågick mellan förskollärare och barn. Det är sedan tidigare känt att en stor del av samtalen i naturvetenskapliga aktiviteter i förskolan består av frågor från förskollärare till barn [15]. Men hur såg det ut med barnens frågor till förskollärarna eller varandra i

videomaterialet? Skulle det gå att identifiera några andra kategorier än "frågor" i samtalen och hur såg i så fall mönstret för dessa ut, i relation till lärandeobjektet? Följande forskningsfråga formulerades till studie 3:

- Hur kan kommunikationen i de olika undervisningssituationerna i undervisningsmodellen beskrivas i relation till lärandeobjektet?

I studie 3 gjordes en ny datainsamling, denna gång från tre av arbetslagen vi följt tidigare, med medverkande barn mellan tre och fem år, samt från två ytterligare arbetslag som arbetade med etttre-åringar. Datainsamlingen skedde i samband med att samtliga arbetslag i

kompetensutvecklingsprojektet skulle prova undervisningsmodellen i sina barngrupper.

Videodokumentation till forskningsprojektet gjordes under samtliga steg i undervisningsmodellen antingen av forskarna eller av arbetslaget själva.

Resultatet från vår analys visade att förskollärarnas och barnens uttalanden kunde delas in i någon av följande fyra kommunikationskategorier: Fråga, Förklara, Beskriva och Visa [17]. Fråga börjar typiskt med Vad, Hur eller Varför och frågorna dyker ofta upp när ett barn eller en förskollärare vill veta mer om samtalsämnet. Med Förklara avses när någon, förskollärare eller barn, ger en förklaring i form av orsak och verkan till någon aspekt av det naturvetenskapliga fenomenet de arbetar med. Ett exempel är när Erland undersöker luftmotstånd genom att jämföra hur en golfboll och en pingisboll faller mot marken. Han upptäcker att golfbollen faller snabbare och förklarar detta med att "den här (golfbollen) var tyngre och den där (pingisbollen) hade bara luft". Beskriva innebär att förskollärare eller barn sätter ord på något de upplever i lärandesituationen. Ett exempel är när en förskollärare tillsammans med barn som är två år arbetar med balans och hon 
säger till ett av barnen att "Nu står jag här på den breda balansbanan och du står på den smala". Genom att beskriva och sätta ord på situationen vidgar eller expanderar förskolläraren barnens möjlighet att förstå och urskilja vad de erfar, i detta fall en bredare och en smalare del av en balansbana. Den fjärde samtalskategorin är Visa och denna innebär olika gester, ofta ihop med beskrivningar, som när förskollärare eller barn pekar mot ett objekt de har i fokus. Gesterna kan också användas ordlöst, vilket är fallet i följande situation där förskolläraren och barnen tillsammans tittar på en timelapsefilm där vattenånga stiger från en flaska med kokande vatten:

\begin{tabular}{|l|c|}
\hline Förskolläraren & Titta här, röken, ångan kommer upp. \\
\hline Marcus & [Visar en flytande, uppåtgående rörelse med sin hand] \\
\hline
\end{tabular}

Vid en närmare analys av de fyra kommunikationskategorierna kunde vissa mönster urskiljas. Resultatet visade att både förskollärare och barn var aktiva i kommunikationen runt lärandeobjektet under varje undervisningssituation men kategorierna fördelade sig på olika sätt mellan dem. Kategorin Beskriva innehöll den största andelen uttalanden och dessa var ganska jämnt fördelade mellan förskollärare och barn, oavsett barnens ålder. Kategorin Förklara innehöll tvärtom minst antal uttalanden från både förskollärare och barn; i undervisningssituationerna med de yngsta förekom kategorin överhuvudtaget inte. En möjlig förklaring skulle kunna finnas i att förskollärarna aktivt väljer att inte förklara hur något ska förstås. Många förskollärare utgår från en föreställning om att barn ska reflektera och undersöka själva istället för att matas med information men risken med detta förhållningssätt är att förskollärarna tar barnens lärande för givet och som något som sker spontant utan stöd. Forskning visar också att barn i de här situationerna kan lämnas ensamma i sitt meningsskapande [15]. Kategorin Fråga dominerades generellt av förskollärarna i undervisningssituationerna och oavsett lärandeobjekt eller barnens ålder är det bara i ett fåtal fall barnen ställer frågor. Varför det ser ut så här är svårt att säga men när det gäller förskollärarna skulle det kunna handla om ett medvetet val. Som diskuterades ovan finns i förskolan en utbredd föreställning om att barn själva ska tänka och försöka dra sina egna slutsatser, något som skulle kunna leda till att förskollärarna ställer många frågor. Användningen av gester och kategorin Visa förekommer i samtliga barngrupper men skiljer sig i frekvens mellan dem. Gester är vanligare i de yngre åldersgrupperna än bland de äldre, där den verbala kommunikationen tar större plats.

\section{Diskussion om studiernas fynd}

I de här tre studierna $[13,16,17]$ bidrog resultaten till att belysa kommunikationen i undervisningssituationer som inkluderar naturvetenskap och datorplattor. För att barn ska kunna lära om naturvetenskap behöver förskollärare upprätta en intersubjektivitet genom ömsesidig samtidighet i kommunikationen med barnen. Med andra ord behöver förskollärarna utgöra en länk mellan barnens perspektiv och lärandeobjektet. Länken till lärandeobjektet underlättas av kroppsspråk och pekande samt användande av ett expansivt språk. När förskolläraren använder ett så kallat lokalt språk i form av till exempel orden "den" eller "det", istället för de mer specifika orden "stenarna" eller "glasburken", minskar barnens möjlighet att förstå det aktuella lärandeobjektet. Intressant nog pekade våra exempel på brott i intersubjektiviteten också på en lösning i form av det vi kallar intermediära lärandeobjekt. Dessa "steg på vägen" utgår från barnens tidigare erfarenheter eller brist på sådana, och om de hanteras av förskolläraren underlättas barnens resa mot att förstå det övergripande lärandeobjektet.

Intressant från resultatet i den tredje studien var också att ingen koppling kunde ses mellan användningen av digitala verktyg och kommunikationsmönstret i form av de fyra kategorierna Fråga, Förklara, Beskriva och Visa. Detta går på tvärs med resultatet i en tidigare studie vi gjort [8] där filmskapande med datorplattor visades stödja barnens diskussioner och reflektioner om det naturvetenskapliga innehållet. Värt att påpeka är att resultaten i den nuvarande studien bygger på 
frekvensen av de fyra olika kommunikationskategorierna medan resultaten i pilotstudien [8] innebar ett mått på hur reflekterande och avancerade barnens uttalanden var. Analyserna av kommunikationen i de två studierna är därmed inte fullt jämförbara. En djupare analys av de fyra kommunikationskategorierna i relation till barns meningsskapande är av intresse och kommer att vara fokus i en kommande studie.

Under det här kompetensutvecklingsprojektet har vi även diskuterat vikten av att man inom ett arbetslag i en förskola pratar ihop sig och enas om en förklaringsmodell för den fysik eller kemi som är av intresse för undervisning. Förklaringen utgör en viktig del av lärandeobjektet och sätter ramarna för hur man som förskollärare tänker och kommunicerar under aktiviteterna och möjliggör för barnen att lära sig om fenomenet. Arbetslagen har ofta kommenterat styrkan i att ha diskuterat och enats om en gemensam förklaringsmodell. Samtidigt visar studierna att det krävs mer än att arbetslaget enas om en förklaringsmodell när man arbetar med naturvetenskap. Till exempel visar det sig att det är en styrka med en samsyn avseende lärande och undervisning, det vill säga att undervisningen gynnas av om arbetslaget utgår från gemensamma principer för barns lärande, väl förankrade i såväl beprövad erfarenhet som vetenskap.

Sammanfattningsvis leder samtliga resultat beskrivna i den här artikeln oss till en och samma slutsats. För att man som förskollärare ska kunna skapa möjlighet för barn att lära behöver man inta två perspektiv samtidigt. Det ena perspektivet är barnens, vad de uttrycker i en specifik situation, och det andra perspektivet rör lärandeobjektet i fokus. Det handlar om "var är vi och vart ska vi". Som vi beskriver ovan behöver det finnas en ömsesidig samtidighet, en länk mellan barnets perspektiv och lärandeobjektet.

\section{Författare}
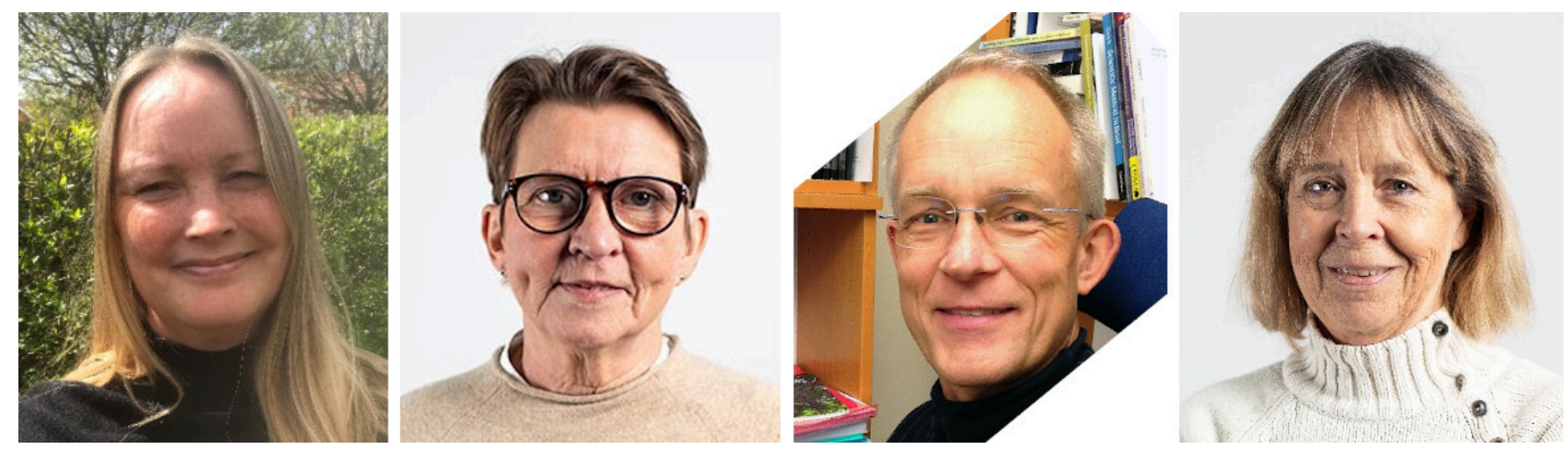

Författarna Marie Fridberg, Agneta Jonsson, Andreas Redfors och Susanne Thulin, alla vid Högskolan Kristianstad.

Marie Fridberg är docent och biträdande professor i naturvetenskapernas didaktik vid Högskolan Kristianstad. Hon är doktor i medicinsk vetenskap och förskollärare och undervisar i naturvetenskapernas didaktik vid förskollärarprogrammet. Maries forskning handlar om yngre barns lärande om naturvetenskap, med och utan digitala verktyg.

Agneta Jonsson är docent och biträdande professor i barn-och ungdomsvetenskap och arbetar med förskollärarutbildning, forskning och uppdragsutbildning vid Högskolan Kristianstad. Förutom undervisning på HKR sedan 1998 finns 20 års erfarenhet som förskollärare i förskola-skolafritidshem. Intresset för förskolefrågor har funnits med genom hela yrkeslivet och koncentreras i olika forskningsprojekt gärna till undervisning samt till de yngre barnens barndom, lärande och utveckling inom förskolan som institution.

Andreas Redfors är docent och professor i fysik - inriktning fysikdidaktik. Han undervisar i fysik, 
astronomi och naturvetenskapernas didaktik, främst inom lärarutbildning. Han leder forskargruppen Learning in Science and Mathematics. Hans huvudsakliga forskningsintresse är naturvetenskapens natur, med speciellt fokus på betydelsen av teoretiska modeller för lärande och undervisning av fysik, såväl med som utan stöd av digitala tekniker.

Susanne Thulin är legitimerad förskollärare, fil dr. och docent i pedagogik med anställning som bitr. professor i pedagogik vid Högskolan Kristianstad. Susanne undervisar vid förskollärarutbildningen samt vid fortbildning och påbyggnadsutbildning för yrkesverksamma förskollärare och lärare, hon har också erfarenhet från programansvar för förskollärarutbildningen vid HKR. Hennes forskningsintresse riktas mot barns lärande och undervisning av naturvetenskap i förskolan med särskilt fokus på kommunikation.

\section{Referenser}

1. Skolinspektionen. Förskolans kvalitet och måluppfyllelse - ett treårigt regeringsuppdrag att granska förskolan. 2018;

2. Redfors A. Att arbeta med teoretiska förklaringsmodeller i förskolan. I: Thulin S, redaktör. Naturvetenskap i ett förskoleperspektiv: kreativa lärandeprocesser. Malmö: Gleerups Utbildning AB; 2016.

3. Skolverket. Läroplan för förskolan 1998/2010. 2010.

4. Skolverket. Läroplan för förskolan 2018. 2018.

5. Vetenskapsrådet. God forskningssed. 2016.

6. Lindgren AL, Sparrman A. Om att bli dokumenterad: Etiska aspekter på förskolans arbete med dokumentation. Pedagogisk forskning i Sverige. 8(1/2):58-69.

7. Fridberg M, Thulin S, Redfors A. Fysik, vattnets faser och datorplattor. I: Stolpe K, Höst G, redaktörer. Från forskning till fysikundervisning: Bidrag från konferensen i Malmö 14-15 mars 2016. Naturvetenskapernas och teknikens didaktik, nr 1; 2016.

8. Fridberg M, Thulin S, Redfors A. Preschool children's collaborative science learning scaffolded by tablets. Research in Science Education. 2018;48(5).

9. Marton F, Booth S. Learning and awareness. Mahwah, NJ: Lawrence Erlbaum Associates; 1997.

10. Marton F. Necessary conditions of learning. New York: Routledge; 2014.

11. Doverborg E, Pramling N, Pramling Samuelsson I. Att undervisa barn i förskolan. Malmö: Liber; 2013.

12. Rommetveit R. On message structure: A framework for the study of language and communication. London: Wiley; 1974.

13. Fridberg M, Jonsson A, Redfors A, Thulin S. Teaching chemistry and physics in preschool: A matter of establishing intersubjectivity. International Journal of Science Education. 2019;41(17).

14. Ivarsson J. Kids in Zen: Computer-supported learning environments and illusory intersubjectivity. Education, Communication \&amp; Information. 2003;3(3).

15. Thulin S. Lärares tal och barns nyfikenhet: Kommunikation om naturvetenskapliga innehåll i förskolan (avhandling). Göteborg: Acta universitatis Gothoburgensis; 2011.

16. Fridberg M, Jonsson A, Redfors A, Thulin S. The role of intermediary objects of learning in early years chemistry and physics. Early Childhood Education Journal. 2020;48(5).

17. Thulin S, Jonsson A, Fridberg M, Redfors A. Communication on Physics Teaching in Preschool. European Early Childhood Education Research Journal. 2021. 